\title{
Norms and Teachings in the Art of Lovemaking of Kings in Ancient Javanese Manuscripts
}

\author{
Sahid Teguh WIDODO \\ The Faculty of Humanities, Universitas Sebelas Maret, Surakarta, Indonesia. \\ Email: sahidteguhwidodo@yahoo.com
}

\begin{abstract}
The specific goal of this research is to discover the concept of the teachings and norms in the art of lovemaking among the royal elite, in particular Ancient Javanese kings of ancient Javanese manuscripts. Based on its format and character, this research is qualitative-descriptive. The primary data sources for the research are an ancient Javanese manuscript Serat Nitimani and information obtained from interviews with Javanese cultural experts. Other supporting data for the research comes from the Javanese manuscript Serat Kadis Saresmi. The data analysis techniques were both interactive (with informants) and non-interactive (literary). The results of the research show: (1) How to Identify The Human Erogenous Zones, (2) lovemaking behaviour, (3) six stages in the Javanese Art of Lovemaking, (4) a description of the concept of Martabat, or the art of taking care of an unborn child in the womb, and finally (5) the existence of a figure known as Guru Laki who played a role in the sexual lifestyle of the Javanese kingdom. The teachings about lovemaking of the Javanese kings provide a way for learning about the secrets behind the greatness of the kingdom in days gone by. The discovery of knowledge about the status and norms of sexual relations is considered of great importance and holds a high position in the Javanese community.
\end{abstract}

Keywords: lovemaking, teachings, sexual, Java

\section{Introduction}

The Indonesian nation has undergone several changes in terms of its categorization of era. The various categories of era include traditional-patrimonial, capitalist, technocratic, modern-digital, and cybernetic virtual - a form of disruptive innovation (Widodo, 2017). One interesting phenomenon is the ever-increasing enthusiasm to look for new sources of orientation in old materials, namely Ancient Javanese manuscripts (Baried, 1985). Ancient Javanese manuscripts contain various kinds of information (Behrend, 1990), one of which is on the art of lovemaking, including the ethics of sexual relations, suggestions and prohibitions, and the effects of misusing or perverting sexual relations.

The art of lovemaking addressed in this research covers three aspects: worldviews (in Ancient Javanese manuscripts), the response and process of acceptance (in the Keraton or Royal Court), and the traditional sex life of the Javanese (see also Suseno, 1991). Knowledge about the sexual lifestyle of ancient Javanese kings can be traced from a variety of different sources (Haryati, 1973), including Ancient Javanese manuscripts, stories from shadow puppet plays, sources from oral traditions, and stories on temple reliefs found in abundance across the Island of Java (Baried, 1985).

(C) AesthetixMS 2020. This Open Access article is published under a Creative Commons Attribution Non-Commercial 4.0 International License (http://creativecommons.org/licenses/by-nc/4.0/), which permits non-commercial re-use, distribution, and reproduction in any medium, provided the original work is properly cited. For citation use the DOI. For commercial re-use, please contact editor@rupkatha.com. 
The sources from shadow puppet stories include a scene known as Murwakala, which tells the story of the birth of Bathara Kala resulting from an act of deviant sexual behaviour by Bathara Guru and Bathari Uma on the back of Lembu Andini (Kamajaya, 1986). In short, Bathari Uma did not serve the desires of Sang Raja Dewa willingly and as a result, the sperm (kama) of Bathara Guru fell into the ocean and was transformed into the figure of Bathara Kala, the 'god of destruction'.

Another story is Babad Lokapala, which tells of the romantic encounter between two people overcome by lust, namely Maharsi Wisrawa and Dewi Sukesi (Hadisismito, 1973). The result of these sexual relations controlled by lust was the birth of (1) Rahwana, who had an angry character and behaved like a wolf; (2) Kumbakarna, who loved to eat and sleep, and behaved like a pig; (3) Sarpakenaka, who suffered from hyper sexuality (a reflection of the behaviour of a serpent/sarpa or penis). When Wisrawa and Sukesi became aware of their children's characters, they repented and promised to engage only in proper sexual relations. As a result of these proper sexual relations, a fourth child was born: (4) Wibisana, who was wise and kind, a reflection of human behaviour (Harjowirogo, 1955).

Another story is that of Maharsi Wiyasa (Abiyasa), who was endowed with an ugly face (black and fearsome) and had sexual relations with three women from the Palace of Astina in order to ensure the continued line of descent of Bharata. The first woman, Ambika, covered her eyes in disgust and fear during the sexual act and subsequently gave birth to Destarastra who was blind from birth. The second woman, Ambalika, turned away her face, deathly pale with fear, and subsequently gave birth to Pandu who was born deformed with his face turned to one side. The third woman was a palace servant without a name and she gave birth to Widura who was born with a deformed leg.

Sources from oral traditions include the story of Ular Baruklinthing who was born as the result of an illicit affair between a young maiden - daughter of Resi Nyamo - and a stranger. The affair resulted in the birth of a giant serpent which is said to have been so long that its body could encircle the entire mountain of Merapi in Magelang. The snake was slaughtered and its tongue turned into a sharp spear which became the heirloom Kyai Baru klinthing.

Ancient Javanese manuscripts are an important source for this research (Marsono, 2013). Serat Nitimani (here on abbreviated to Nitimani) and Serat Kadis Saresmi (here on abbreviated to Kadis Saresmi) are two Ancient Javanese manuscripts which contain information about the Javanese art of lovemaking. Nitimani contains knowledge about the ethics of engaging in sexual relations. Nitimani was composed by Raden Mas Tumenggung Haryosugondo in $1887 \mathrm{AD}$ and has been transliterated into Latin script making it easier to study. Kadis Saresmi is a part of Serat Centhini which is well known as a Javanese encyclopaedia. This manuscript contains sex education for couples hoping for good quality offspring, and uses as its background the example of the Prophet Muhammad SAW and his advice to his daughter Siti Fatimah and his son-in-law, Ali. The teachings also include prohibitions and suggestions for sexual intercourse.

Information about Javanese lovemaking can also be found on the Karmawibhangga relief on the lower level of Borobudur Temple as well as on a number of reliefs on Sukuh Temple and Cetho Temple. On Penataran Temple in Blitar, East Java, a relief depicting lovemaking is buried under the ground or floor. This relief portrays a sexual orgy that knows no ethics or norms (Ki Padmosumanto, 1990). This type of sexual behaviour depicts the lowest level of a human character. It is so low, even, that it is ignored in the process leading towards a perfect human being. 
Sources found in Javanese manuscripts are more beneficial because they are more comprehensive in presenting teachings about the Javanese art of lovemaking. Ancient Javanese manuscripts are authentic documentary evidence that still exist (Mulyono, 1989) and their contents discuss in great depth and detail the 'art of lovemaking', or Aji Asmaragama. After taking a close look at the sources mentioned above, the research determined the focus of the study and the main source and other materials to be used as additional supporting sources.

\section{Experimental}

The form of this research is qualitative-descriptive with a tendency to use an inductive approach (Miles \& Huberman, 1988). According to its type, it is library research which utilizes data sources in the form of texts from Ancient Javanese manuscripts. Based on the result of a catalogue study, Serat Nitimani (hereon abbreviated to Nitimani) was selected as the primary data source. In addition, the research also uses data from interviews with Javanese cultural experts. Secondary data sources were obtained from other similar studies on Javanese sexology and another similar type of manuscript, Serat Kadis Saresmi (hereon abbreviated to Kadis Saresmi). The approach used is a literary approach as recommended by Ratna (2010) and Gerardet (1983).

This research does not include the process of transliteration of the manuscripts because the Nitimani manuscript used was composed by Raden Mas Tumenggung Haryosugondo (1887) and transliterated by Sumarni (2000). This manuscript is currently kept in the Javanology Institute library, LPPM UNS Surakarta. The secondary source used is the Kadis Saresmi manuscript from the collection of the Reksa Pustaka Library at the Mangkunegaran Palace in Surakarta, which was transliterated by an unknown scholar in 1885 , with the catalogue number: KS 356B/332Ra SMP153/16. After selecting the data sources, the next two stages of the study were to read and understand Nitimani carefully and in detail, and then to make a record of all the data and display the data. Any data that was not found in Nitimani was then searched for in Kadis Saresmi using the same technique. The techniques of data analysis used were content analysis and interviews because the research also makes use of information obtained from court employees (abdi dalem) and family members (sentana) of the Surakarta court, as well as cultural experts, artists, and Javanese scholars.

All the data obtained from the different sources was classified based on the research problem. The next step was to interpret the data. Each character in the problem was interpreted carefully and in detail. The final step was the verification of data (drawing a conclusion) as a form of answering the research problem. In other words, the process of data analysis was carried out using an interactive technique in the form of data reduction, data presentation, and data verification (Miles \& Huberman, 1988).

\section{Results and Discussion}

\section{How to Identify the Human Erogenous Zones}

Java has a wealth of knowledge (Javanese=ngelmu) about calculations (petangan). A special kind of sexual Javanese petangan is used to open up the door to a woman's desire and pleasure (Otto, 2002). Nitimani even takes into account the calculation of days, as seen in the extract below:

Serat Nitimani duk nalika amurweng gita jroning warsa lumaksana, tinengran candrasangkala "rasaning janma kaesti juga". Mangkya wau kang pustaka ing karsa arsa 
tinata kaewuh aranira kawewahan lan rinengga. Duk kala pangriptanira, aniti pranata mangsa almanac taun Jawa purnama ing wulan Sela, Kurantil ing Wukunira panuju ing mongsa sada. Tinengran candra-sangkala "amandeng ngesti bathara.

\section{Translation:}

When Serat Nitimani was composed, it was marked with a chronogram (candra sangkala) as a cryptic way of expressing 'the year of its composition', which reads rasaning janma kaesti juga' (Javanese year 1816 or 1887 AD). The text was written using beautiful words. Its composition pays close attention to the Javanese agricultural (solar) calendar - pranatamangsa. The night of the full moon in the month of Sela, the cycle (Wuku) Kurantil, the season of Sada is marked by the chronogram mandeng ngesti bathara, (Javanese year 1821 or 1887 AD).

Many cultural experts in the past used these Javanese calculations as the basis for their lives. They understood character, disposition, fortune, disturbances, joy, and sorrow through careful calculations (petangan) according to the Javanese calendar system which is based on the rotation of the moon. It is interesting that in connection with Javanese sexology, specifically with reference to identifying the erogenous zones and points of sexual arousal for women, there is also knowledge based on such calculations (petanganJawa). Below is the opinion of a cultural expert from the KaratonKasunanan in Surakarta.

"Determining the erogenous zones on a woman's body is empirical knowledge that has strong Hindu, Javanese, and Islamic influences. The essence of the knowledge of these teachings shows that the culture of the Javanese people pays great attention to the quality of offspring produced as a result of sexual intercourse. Good quality offspring must be achieved through a process that is also of a high quality".

(KRHT. Budayaningrat, interview, 21 November 2017).

Javanese teachings on eroticism appear in symbolic form in various textual sources and manuscripts. This is only natural because sex is an instinctive need and a basic obsession of human beings (Setyawati, 2006). Every ethnic group in Indonesia has its own special ways and techniques (Heru Satoto and Suyadi, 2004). Various forms of symbols and bases for calculations are used. From the numerous existing sources it can be seen that calculations are based on seasons, the value of days and months, direction, and the appropriate time for engaging in sexual intercourse (Hariwijaya, 2004).

Table 1: Time and location of erogenous zones on a woman's body

\begin{tabular}{cccc}
\hline & Right Side of the Body & \multicolumn{2}{c}{ Left Side of the Body } \\
\hline Date & Erogenous Zone & Date & Erogenous Zone \\
\hline 15 & between the two eyebrows & 16 & between the two eyebrows \\
14 & end of the nose & 17 & end of the nose \\
13 & lips (middle part) & 18 & lips (middle part) \\
12 & middle of the chin & 19 & middle of the chin \\
11 & middle of the breast & 20 & middle of the breast \\
10 & middle of the vagina & 21 & middle of the ankle \\
9 & middle of the buttock & 22 & navel \\
8 & middle of the thigh & 23 & middle of the vagina \\
7 & end of the knee & 24 & middle of the buttock \\
6 & middle of the calf & 25 & middle of the thigh \\
5 & middle of the ankle & 26 & end of the knee \\
4 & middle of the heel & 27 & middle of the calf \\
3 & & 28 & middle of the heel
\end{tabular}




\begin{tabular}{lccc}
\hline 2 & middle of the sole of the foot & 29 & middle of the sole of the foot \\
1 & end of the big toe & 30 & end of the big toe \\
\hline
\end{tabular}

As an example of the use of these calculations, when a husband and wife have sexual intercourse on the $7^{\text {th }}$ day of the month, the husband should stimulate or arouse his wife by kissing her right thigh because according to the calculations, the woman's 'centre of desire' is in that place, and so on. Nevertheless, aside from this knowledge about a woman's erogenous zones, it all depends on the power of concentration and readiness for making love.

Lamun tandhing/ marsudya ing tyas ening/ amrih ering/ kang supadi tan kajungking// Yen sembrana/ den prayitna sampun lena/ lamunina/ sayeka manggih weda// (pupuh 2)

Translation:

When competing, try to keep a tranquil heart in order to guard one's concentration and not be defeated. If one is careless, beware so as not to be remiss, it is truly painful.

Thus, if this technique is implemented well, the pleasure of sexual intercourse can be enjoyed together.

"Teachings about the sexual union of a man and a woman (coitus) are not purely Javanese because they also contain Hindu, Islamic, local Javanese, and Western influences. Our Javanese ancestors formulated the teachings and they became endemic to Java. The success of sexual intercourse (coitus) is determined by numerous factors. The couple's health, mental state, mood, and many other supporting factors. This technique is only popular knowledge that is important to be tried and proven. And you will be surprised."

(KRHT. Sunoto, interview, 1 October 2017).

\section{Lovemaking Behaviour}

The Javanese people have unique rules and norms, specifically in connection with the art of lovemaking. After reading and understanding the two Ancient Javanese manuscripts mentioned above, it was learned that ancient Javanese society tended to be very cautious about engaging in sexual intercourse. Sexual intercourse (due to Islamic influence) may only be partaken in by a legally married couple. The goal of sexual intercourse is to 'produce offspring' (hanerusaken turas). Serat Kadis Saresmi legitimizes the relations between a man and wife by taking an example from the teachings of the Prophet Muhammad in which he gives advice to his daughter, Siti Fatimah, and his son-in-law, Ali.

The procedure for engaging in sexual intercourse, along with the appropriate choice of time, place, situation, and conditions is important in Ancient Javanese teachings because it is a precondition for giving birth to good quality offspring. Mistakes in lovemaking (kama salah 'wrong kama') will give birth to a bad generation, destructive to ethics and morals, and it's causes distruction on earth. So, It requires the right knowledge, experience, and skills to produce a healthy and devine lovemaking (kamabener 'right kama'). There are of course other preconditions such as good physical health, especially in the scrotum of the man (Nitimani, n.d.: 11). 
Table 2: Prohibited Behaviour at the Time of Sexual Intercourse and Consequences

\begin{tabular}{|c|c|c|}
\hline Source & Prohibited Behaviour & Consequence for children born \\
\hline Ilat 'speech' & $\begin{array}{l}\checkmark \text { Talking a lot during } \\
\text { intercourse } \\
\checkmark \text { Swearing, talking dirty, } \\
\text { gossiping about people }\end{array}$ & $\begin{array}{l}\quad \text { Child who talks a lot and cannot } \\
\text { keep still (hyperactive) } \\
\checkmark \text { Child who likes to talk dirty, } \\
\text { cannot keep quiet, and likes to } \\
\text { deceive others }\end{array}$ \\
\hline $\begin{array}{l}\text { Glagat 'sexual } \\
\text { behaviour' }\end{array}$ & $\begin{array}{l}\checkmark \text { Behaving strangely } \\
\text { (unnaturally) } \\
\checkmark \text { Imitating the behaviour of } \\
\text { animals, behaving improperly } \\
\text { to chase a fantasy }\end{array}$ & $\begin{array}{l}\checkmark \text { Child who is naughty and } \\
\text { difficult to control, rude, hard to } \\
\text { manage } \\
\checkmark \text { Child who enjoys violence, is } \\
\text { impolite, wild, and rebellious }\end{array}$ \\
\hline $\begin{array}{l}\text { Ulat } \\
\text { expression' }\end{array}$ & $\begin{array}{l}\checkmark \text { Turning away or covering } \\
\text { the face with the hand } \\
\checkmark \quad \text { Looking sullen and gloomy } \\
\checkmark \quad \text { Becoming too immersed in } \\
\text { the fire of passion }\end{array}$ & $\begin{array}{l}\checkmark \text { Child who is physically and } \\
\text { mentally disabled } \\
\checkmark \text { Child who is moody } \\
\checkmark \text { Child who is shameless }\end{array}$ \\
\hline
\end{tabular}

\section{Six Stages in the Javanese Art of Lovemaking}

The sexual behaviour of the Javanese is apparently not only to satisfy biological desires (Hariwijaya, 2014). It has the additional goal of seeking true and indescribable pleasure (Hendro, 2001). Nitimani implicitly explains that true pleasure is a pleasure that is not easily destroyed, an everlasting pleasure which is born along with a baby that is the fruit of good sexual relations. This kind of pleasure is longed for by everyone and is sought through knowledge, feelings, and cultivated skills (Sumarno, 2008). Verse 28 of Serat Nitimani explains:

kudu resik atiku, atiku kudu suci, rasaku kudu idhep, jiwaku kudu madhep, sawuse banjur kudu kulina ing gelem, taberi ing karem, kang mangkono ancas lakuning kadonyan kayakaya wus nyukupi kanggo sarana mawas tetesing kasidan jati

Translation:

My heart must be clean, my heart must be pure, my feelings must know it, my spirit is ready, hereafter to become accustomed and desired, to follow its will, thus the direction of worldly conduct appears to be sufficient as a means of introspection about the end of real life.

Ancient Javanese society identified 6 (six) levels of lovemaking that are related to knowledge and skills in the art of lovemaking, as follows:

\section{Asmarasabda}

This is literally a derivative of the words asmara 'love, romance' + sabda 'word'. Asmarasabda is referred to as the first level. Asmarasabda is a technique of flattery or the use of alluring words. The goal of asmarasabda is to cause feelings of love to grow between the couple.

\section{Asmaraturida}

This is literally a derivative of the words asmara 'love, romance' + turida 'sympathy'. Asmaraturida is a way of causing the spirit of love to grow by evoking sympathy between the couple 
Asmaraturida is also a technique for training the memory by observing the partner's entire body in detail in order to strengthen both memory and admiration.

\section{Asmaracipta}

This means "love + creative power (thought; imagination)". Asmaracipta is the art of increasing mental sexual arousal through a technique of intercourse which uses the imagination, not only in a physical sense or as a fantasy. Sexual intercourse is something that is natural and definite, but its manifestation is achieved by the power of imagination, the power of reflection, and a sense of beauty. Ultimately, it all becomes the couple's prayer for a perfect child.

\section{Asmarawanita:}

This is literally a derivative of the words asmara 'love, romance' + wanita 'woman'. Asmarawanita is knowledge about the covert and overt pleasures of a woman, both inside and out, or the erogenous zones of the body. If these particular spots are touched gently, appropriately, and in the right way, the woman's passion is like a fire that flares up violently.

\section{Asmaragama:}

This is lite rally a derivative of the words asmara 'love', romance + gama 'sexual intercourse'. Asmaragama is a technique of sexual intercourse in which the goal is for the man and woman to both reach pleasure and satisfaction together so that both can experience a climax.

\section{Asmaratantra:}

This means "love + all things (ngabehi)". Asmaratantra is a technique for preserving the man's strength. This technique relies on the power of concentration and avoiding disturbances in order to achieve the best possible quality in the sexual intercourse.

Apart from seeking pleasure, these six levels of sexual intercourse have the additional goal of producing offspring with a superior quality (wiji sejati). Indeed, the Javanese culture recognizes knowledge about the procedure of sexual intercourse as a way for producing a 'superior seed'. This large theme gave rise to a response from the Javanese community which in turn led to the concept of "bibit" ('seed'), "bobot" ('weight, quality'), and "bebet" (wealth, worldly traits) as a means or strategy for selecting a prospective spouse.

Para sujanma priya yen badhe amilih dhateng wanodya, kaagem pantesing palakrami, anyep lesan dhateng suraosing tetembungan tiga: bobot, bebet, bibit. (pupuh 3)

\section{Translation:}

Men who are intending to choose a woman to marry should pay attention to three things: quality, wealth, and origin.

Bibit [bibIt] looks at a person in terms of his or her origins or ancestry. Bobot [bPbวt] looks at the quality, potential, education, and economic aspects of a person. Bebet [bӘbӘt] looks at a prospective partner's possessions, wealth, and sense of responsibility which lead to loyalty, identity, and commitment, including the wealth of the parents (Sudarto, 2010).

\section{The Art of Taking Care of an Unborn Child in the Womb}


The teachings of Asmaragama or Aji Asmaragama are the culmination of the knowledge of life, in particular about the basic laws of life and the stages of life of anunborn child in the mother's womb. The basic laws of life include fundamental knowledge that should be known and understood in order to produce good quality offspring, as follows:

a. Mani or kama is the man's sperm in the form of a somewhat viscous bluish-white fluid.

b. Madi, the main essence of the mani, is the semen or seed from the man in the form of a somewhat viscous creamy-white fluid.

c. Manikem is the main essence of the madi and is gleaming white, like a jewel.

d. Nukad Gaib is the semen that is stored tidily away in the man's testicles.

The information above is supplemented by Kadis Saresmi, which shows that the Javanese people understand sexual intercourse to be concerned with four things, namely: (1) regulation of the feelings which impacts the trans-quality and maturity of the intercourse, (2) control of the thoughts which impacts the achievement of a maximum result, (3) strengthening of the body, which impacts the endurance and can complement (1) and (2), and (4) possession of skills which impacts pleasure and splendour.

The union of the sperm and egg cell forms the 'pure/original seed' (wiji sejati) and this takes place in a sacred place, the woman's womb. Hence, it can be said that human beings are born from a sacred place (Herusatoto and Suyadi, 2004). Wiji sejati, as described in Nitimani, is an embryothat undergoes an ascetic process (tapa brata) and has already received enlightenment. Sulistyawati (2006) states that many of the Kyai and Javanese High Priests in ancient times advised people to cease engaging in sexual intercourse if the woman was known to be already with child. The reason was so that the foetus would grow in a pure environment (Rono, 2009). However, circumstances today are not the same as in the past. Nowadays, husbands engage more actively in sexual intercourse while their wives are pregnant (Susilantini, 2013). Some say, jokingly, that it is more enjoyable, while others say they are "fertilizing" the seed to make the foetus grow stronger (Wirja, 1954). The Ancient Javanese sexological teachings explain the existence of Seven Natural Levels known as Martabat. Martabat is knowledge about the way of caring for an unborn child while it is in the womb. The explanation is presented in the form of a table below.

Table 3: Knowledge about Taking Care of an Unborn Child in the Womb

\begin{tabular}{|c|c|c|c|}
\hline Level & Age of Pregnancy & Natural Level & Explanation \\
\hline 1 & 1 month & $\begin{array}{l}\text { Alam Akhadiat } \\
\text { (latahyun) }\end{array}$ & $\begin{array}{l}\text { The condition of the foetus still shows early signs of } \\
\text { formation, it is still very weak. The parents should } \\
\text { recognize the signs and eat healthily, avoid going out at } \\
\text { night and stay away from sawan, a strange disease } \\
\text { afflicting infants who are disturbed by supernatural } \\
\text { beings. }\end{array}$ \\
\hline 2 & 2 months & $\begin{array}{l}\text { Alam Wahdad } \\
\text { (tahyumawal) }\end{array}$ & $\begin{array}{l}\text { The condition of the foetus has become more real. The } \\
\text { parents should guard their senses (sight, hearing, } \\
\text { speech, touch, and feel). }\end{array}$ \\
\hline 3 & 3 months & $\begin{array}{l}\text { Alam Wakidiyat } \\
\text { (takyunsari) }\end{array}$ & $\begin{array}{l}\text { The condition of the foetus is becoming more real, has } \\
\text { taken on a simple form, and is still very weak. The } \\
\text { husband and wife should control their sexual relations } \\
\text { properly, increase their time spent in prayer asking God } \\
\text { to give them strength. }\end{array}$ \\
\hline 4 & 4 months & $\begin{array}{l}\text { Alam Arwah } \\
\text { (ahyansabitah) }\end{array}$ & $\begin{array}{l}\text { The condition of the foetus is fully formed. It is } \\
\text { beginning to grow stronger. }\end{array}$ \\
\hline
\end{tabular}




\begin{tabular}{lll}
\hline 5 months & $\begin{array}{l}\text { Alammisal } \\
\text { (akyankariamiyah) }\end{array}$ & $\begin{array}{l}\text { The condition of the foetus has developed into a } \\
\text { perfectly formed human body with the brain and senses } \\
\text { and all early functions. The parents should guard their } \\
\text { speech, thoughts, feelings, and actions. } \\
\text { The condition of the foetus is alive, can feel, and is } \\
\text { growing towards perfection. }\end{array}$ \\
Tlamasjam & $\begin{array}{l}\text { The condition of the foetus is complete, definite, and } \\
\text { fully developed. There is no longer any realm other than } \\
\text { the martabat or maqam as a certain entity. }\end{array}$ \\
\hline
\end{tabular}

A married couple who have 'knowledge about how to take care of an unborn child in the womb' will give birth to a good child. Interestingly, Ancient Javanese society emphasized the need for both husband and wife to undertake certain ascetic practices or 'austerities'. Marriage is more than simply seeking asmaranala, 'joy that comes from sexual pleasure'; it is also to produce good quality offspring. Rono (2009) explains that experience has proven that the birth of a good generation (of kings) is the result of good sexual relations. Nitimani (n.d.: 11) mentions the concepts of nistha, madya, utama. Nistha 'very bad' refers to sexual intercourse that resembles the style of animals. Madya 'moderate' means there has been progress in the knowledge gained, and Utama 'superior' refers to sexual behaviour that is proper and has good intentions, is far from the character of animals.

Kangjeng Raden Mas Restu (June 2, 2017) in an interview stated that there are four ways for achieving eternal pleasure, as follows:

1. Eneng [ӘnӘॄ]: maintaining a calm mood to help prevent premature ejaculation and improve the quality of sperm.

2. Ening [OnIn]: keeping a clear mind to enhance the sense of pleasure during sexual intercourse.

3. Awas [AwAs]: paying close attention to the psychological condition of the partner and not forcing each other to engage unwillingly in sexual intercourse.

4. Eling [ElIn]: focusing the mind and avoiding the temptation of Satan to act in an inappropriate way.

\section{The Sexual Lifestyle of the Javanese Court}

For centuries, the keraton (royal court) was positioned as the centre and source of knowledge and culture for the rest of society. As an example, in the Javanese wedding tradition the keraton was always used as the main point of reference, and this also entered into the area of the sexual lifestyle associated with this tradition (Otto, 2002). The provision of a bridal room that is based on the pattern of a krobongan (an inner room divided by a curtain), the sequence of events and ceremonies with various paraphernalia, the incense and mantras, and the ritual medium were all framed in a strong Javanese tradition (Setyowati, 2006).

The sexual lifestyle in the Surakarta keraton from the end of the $19^{\text {th }}$ century up to the present day can still be traced from verbal sources and stories passed down by word of mouth from one generation to another amongst the keraton elite (nobility and court employees or abdi dalem), as well as from Javanese cultural traditions such as circumcisions or 'cleansing ceremonies' for boys (khitanan), 'cleansing ceremonies' for girls (tetesan [têtêsan]), krobongan, the presence of a "guru laki", and from ancient manuscripts (Nitimani, Kadis Saresmi, etc.). 
The guru laki was a figure whose profession was to teach sexology in the keraton. Outside the keraton walls, the term guru laki was used in reference to a man, head of household, or father in a Javanese home. In fact, the term guru laki was really the title of a court employee whose job was to teach knowledge about sex to the children of the king. This position was held by a woman who was highly skilled and knowledgeable about sexual matters. The job of the guru laki was not only to teach the art of lovemaking or sexual intercourse to the sons and daughters of the king but also to provide information about traditional herbal medicine (jamu) to enhance the sexual experience and other related knowledge.

The guru laki usually also interacted with the king's wives and concubines, of which there were many. According to information from one source, the guru laki was sometimes also ordered to arrange the schedule for all of the concubines to meet with the king.

Kangjeng Sinuwun Pakubuwana kaping sedasa punika nggadhahi seliring kang cacahipun langkung saking cacah 30. Kala rumiyin, ingkang kados mekaten nedahaken hebat, kekiyatan, lan wibaningsun. Menawi sakpunika inggih mboten pas cak-cakanipun, Para selir nggadhahi kewajiban damel remen Kangjeng Sinuwun. Patuh kaliyan adat kukum ingkang sampun dipun tata para abdi guru laki" (Handoyo, interview, 1 November 2017).

Translation:

Sinuhun Pakubuwono $\mathrm{X}$ had over 30 concubines. Formerly, this was to show the greatness, prowess, and authority of the king. Nowadays, it would appear to be no longer appropriate. The duty of the concubines was to serve the king. They obeyed the rota that had been arranged by the abdi dalem guru laki.

The guru laki held the key to the secret of the king's power in the art of lovemaking. It is said that whenever it was the turn of a particular concubine to serve the king, or if he desired a particular concubine at a time other than her scheduled turn, she would have to fast for three days in a row in order to cleanse and purify herself, to make herself fragrant so that she could serve the king to a maximum level. On the contrary, a king who knew no rest would always appear strong and virile because he was always supplied with food and traditional Javanese herbal medicine that would ensure his constant "potency" and "virility".

The explanation given by abdi dalem from the keratin Kasunanan Surakarta about the role of the guru laki is related to the contents implied in the Kadis Saresmi and Nitimani. Essentially, the position of both knowledge and a teacher in the sexual lifestyle of the keraton had three main roles (tri dharma): (1) to see that the princes and sentana dalem (the king's inner family) knew and understood about lovemaking, and could reach the height of sexual pleasure (sajatining pemarem), 2) to explain that the sexual lifestyle of the keraton was the culmination of spiritual pleasure (Kadis Saresmi, n.d.: 11), and that if sexual intercourse was founded on mutual and genuine love it would lead to the highest level (Nitimani), (3) to produce wijisejati, offspring of a high quality who would grow into superior or excellent human beings.

\section{Conclusions}

Javanese Kings have a unique worldview on the life of sexuality. Based on two ancient Javanese manuscripts namely Serat Nitimani and Serat Kadis Saresmi, it can be seen that the palace in Java teaches sex education closely and deeply with two main objectives: (1) achieving the beauty (aesthetic) level of lovemaking, and (2) obtaining superior offspring (wiji sejati 'thrue seed') who have the value, quality, and higher performance (physical and spiritual). 
The Javanese society represented by the kings considers that understanding a good sexuality life is very important. The teachings of sexuality (teachings of life) are poured in various forms of media: ancient manuscripts, temple reliefs, wayang, oral traditions, and many cultural traditions such as traditional herbal medicine, aromatherapy, language, healthy food and drink (sex nutrition), etc. Therefore, further research effort is required. Art of romance (Asmaragama Jawa) has the opportunity to be exposed as a science or discipline that can be attract attention in various joints of life.

Serat Nitimani and Serat KadisSaresi are ancient Javanese manuscripts that have some resemblance to the Kamasutra Book of India. However, in some ways it shows the uniqueness of Javanese cultural setting. These two ancient Javanese manuscripts teach the rules, rules, and ethics of romance. It also contains the concept of Javanese art of love. This manuscript is interesting because it contains good and moral cultivation.

\section{Acknowledgements}

I would like to thank the Department of Higher Education of the Republic of Indonesia for providing the opportunity for research in the fields of Social Humanities, Art and Culture, and Training in Domestic Field Research 2019.

\section{References}

A. H. MD. Alhamidy, (1980). "Islam dan Perkawinan (Cetakan II), Alma'arif, Bandung”.

Anonymous, Babad Lokapala, No. Ca-27-1, Koleksi Sana Pustaka Karaton Kasunanan Surakarta Hadiningrat, N. D.

Anonymous, Kitab Kadis Saresmi, No. Ca. KS 356 B/332 Ra SMP 153 /16, Perpustakaan Reksa Pustaka Pura Mangkunegaran Surakarta, Transliterated by N. N., N. D.

S. B. Baried, Pengantar filologi, (1985). Departemen Pendidikan dan Kebudayaan RI,Jakarta.

R. Gunawan, (2000). Filsafat Seks, Yogyakarta, Bentang.

K. S. Hadisismito, (1973). Pustaka Centhini Selayang Pandang, Penerbit UP Indonesia Yogyakarta.

Hariwijaya, (2004) Seks Jawa Klasik, Niagara, Yogyakarta.

Harjowirogo, Sejarah Wayang Purwa, (1955). Perpustakaan Perguruan Kementrian PP dan K., Djakarta.

S. Haryati, Masalah Filologi, (1973). Paper Seminar Pengajaran Sastra Daerah: Bali, Sunda, Jawa, Yogyakarta.

B. Hendro, (2001). Asmaragama: Seks Indah untuk Kebahagiaan,Lubuk Raya,Semarang.

B. Herusatoto, D.Suyadi, (2004). Seks Para Leluhur,Tinta, Yogyakarta.

Marsono, (2013). Bahasa, Sastra, Seni dan Budaya Jawa sebagai Aset Wisata. Pidato Pengukuhan Jabatan Guru Besar pada Fakultas Ilmu Budaya, Universitas Gadjah Mada, Yogyakarta.

M. Miles, A. Huberman, (1992). Qualitative data analysis. An extended sourcebook (2nd ed.), SAGE Publications, London.

S. Otto, (2002). Seks Para Pangeran, Bentang, Yogyakarta. 
S. Rono, (2009). Pendidikan Seks, Paper, Obstetri dan Ginekologi, FK-UNPAD, Bandung.

S. Setyowati, (2006). Centhini dan Erotisme, Jurnal Ilmiah Kebudayaan, 4(2).

M. Sudarto, (2010). Makna Filosofi Bobot, Bibit, Bebets ebagai Kriteria untuk Menentukan Jodoh Perkawinan menurut Adat Jawa, IAIN Walisongo, Yogyakarta.

Sumarni, (200o). Serat Nitimani: Transliterasi dan analisis budaya Gubahan Raden Mas Tumenggung Haryosugondo 1887, FIB UNS, Surakarta,200o.

Sumarno, (2008). Pendidikan Seks Dalam Sastra Jawa (Studi Terhadap Serat Kadis Saresmi).

E. Susilantini, (2013). Unsur Didaktik Dalam Cerita Ki Ageng Paker, BPNB Yogyakarta, Yogyakarta.

S.T. Widodo, (2017). Membaca Tanda-Tanda Zaman: Perubahan Makna Simbolis, Paper, Universitas Trilogi, Jakarta.

P. Wirja, Asmaragama, (1954). Toko Buku Sadu Budi, Solo. 